\title{
Barrett's esophagus - Who, how, how often and what to do with dysplasia?
}

\author{
Lawrence C Hookey MD
}

$\mathrm{O}^{\mathrm{n}}$ ne of the issues I struggle with in gastroenterology is when, if and whom to screen for Barrett's esophagus (BE). Although it is becoming common practice to screen patients with chronic reflux for $\mathrm{BE}$, questions abound pertaining to whether screening is effective, as well as cost-effective, whom to screen and what to do when BE is found, not to mention the issues that arise when dysplasia is found. In light of the enormous clinical and economical implications of diagnosing patients with $\mathrm{BE}$ (1), some have questioned whether $\mathrm{BE}$ is a reasonable target for screening or whether resources would be better allocated to colon cancer prevention.

Most patients agree to endoscopic screening when explained that the initial endoscopy is performed to search for an abnormal lining of the esophagus which, if present, has the potential to lead to esophageal cancer. What most of us do not explain, in any great detail at least, is what happens when and if dysplasia is found. Until recently, the finding of dysplasia led to anxiety on the part of the patient and physician. The potential therapeutic avenues included more intense surveillance or referral for esophagectomy, with its inherent risks and complications. It is possible that if these risks and complications were explained to patients in the beginning, a higher proportion would opt out of a surveillance program. On the other hand, there is evidence that suggests that the majority of patients overestimate the risk of developing adenocarcinoma of the esophagus, and this is worsened in patients who research their condition on the Internet (2), thus making our role as physicians and patient educators even more important. With the advent of more advanced and efficacious endoscopic therapy for dysplasia in BE, one hopes that the transition from diagnosis of BE to therapy of dysplasia will be smoother.

\section{DEFINITION AND EPIDEMIOLOGY}

The definition of $\mathrm{BE}$ has gone through several renditions to arrive at its current form: the presence of columnar-lined esophagus with specialized intestinal epithelium confirmed on biopsy. In the literature, the length of BE has been classified into long segment $\mathrm{BE}$ ( $3 \mathrm{~cm}$ or greater) and short segment $\mathrm{BE}$ (less than $3 \mathrm{~cm}$ ). Although, when first described, short segment BE was thought to be associated with a much lower risk of esophageal adenocarcinoma, current evidence suggests that this risk is still significant and one cannot treat these patients differently than those with long segment BE $(3,4)$. The risk estimation of esophageal adenocarcinoma in patients with $\mathrm{BE}$ varies widely, ranging from one per 99 patient years to one per 300 patient years $(3-8)$.

It is suggested that the incidence of adenocarcinoma has been steadily rising over the past 30 years $(9,10)$. A significant majority of esophageal adenocarcioma arises from BE. The exact prevalence of $\mathrm{BE}$ is debatable, and has ranged from $0.4 \%$ (11) to $25 \%$ (12), depending on the study and the methodology used. Many studies (13-17) examined patients with reflux symptomatology and found higher rates of $\mathrm{BE}$, while general population studies $(15,18)$, which are much more difficult to perform, seem to suggest a much lower prevalence. A recently published report from Sweden (18) recruited a large random sample of the general population $(n=1000)$, endoscoped them, and found BE in 16 individuals (1.6\%). A North American study (15) of 961 individuals undergoing colonoscopy screening who also agreed to an endoscopy, reported a prevalence of $6.8 \%$. While it may be reasonable to agree that the prevalence is somewhere between $2 \%$ to $6 \%$ in the general population, small changes in these estimates can dramatically affect calculations and modelling of costeffectiveness of screening strategies. These epidemiology studies have allowed the identification of people at higher risk of developing BE, confirmed that it is linked to acid reflux, and that the extent of BE correlates with the degree of acid exposure (19). Other risk factors include patients older than 50 years of age, male, Caucasian, presence of a hiatus hernia, alcohol abuse and smoking $(15,18)$. In spite of this knowledge, the prevalence of $\mathrm{BE}$ in patients without these risk factors is significant enough that screening only patients with known risk factors would miss too high a proportion of affected individuals.

\section{ENDOSCOPIC SCREENING OF BE: IS THERE ANOTHER WAY?}

The current standard for screening for dysplasia in BE involves taking four-quadrant biopsies every $2 \mathrm{~cm}$ of affected esophagus using jumbo biopsy forceps (the Seattle protocol [20]). Concerns with this type of surveillance include the time it takes to perform the screening and the relatively small proportion of tissue sampled. Hence, much effort has been expended in an attempt to enable endoscopists to perform targeted biopsies of areas suspected for dysplasia. Endoscopically 
evident lesions (such as nodules, strictures or BE ulcer) should be biopsied extensively because they are at higher risk for harbouring dysplastic tissue (21). However, in the absence of such lesions, nonenhanced endoscopy is incapable of distinguishing dysplastic from nondysplastic tissue. Chromoendoscopy using methylene blue, which reversibly stains absorbent cells such as intestinal epithelium, has been studied in a number of prospective trials (22-26), with conflicting results. The current evidence $(22,23)$ suggests that although it may help target biopsies, it does not dramatically reduce the number of biopsies necessary, and actually lengthens the time of the procedure $(25,26)$. Other techniques studied have similar results (fluorescence [27-31], enhanced magnification endoscopy [32] and optical coherence tomography [33-35]) or are currently too complicated and/or time consuming to use in daily practice (spectroscopy $[36,37]$ ). A new technique that seems promising is narrow band imaging (38), which seems user friendly and not very time consuming, however, more data are necessary to determine its efficacy.

\section{SHOULD THEY ALL HAVE FUNDOPLICATION?}

Long-term acid suppression is recommended for all patients diagnosed with BE. Treatment with proton pump inhibitors is associated with partial regression of the length of affected esophagus (39), but the clinical significance of this is unclear. There are numerous reports of partial regression of BE after fundoplication operations, with some centres reporting a high proportion of patients (33\%) having complete regression (40), but most do not have quite such good results (41-43). Some authors have combined endoscopic ablation techniques, such as argon plasma coagulation, with fundoplication, and reported promising preliminary results (44). Nonetheless, in the setting of a patient with BE whose reflux is well controlled on proton pump inhibitors, there does not seem to be a compelling reason to undertake the risk and recovery time of a surgical fundoplication in the absence of other indications.

\section{SURGERY AND BE}

Traditional therapy for high-grade dysplasia (HGD) and/or intramucosal adenocarcinoma arising from $\mathrm{BE}$ is a surgical esophagectomy. This is a major surgery with significant potential for mortality and morbidity. Surgical series (45-48) published in the past 20 years still report mortality ranging from $3.3 \%$ to $11.2 \%$. Complications are also common after surgical esophagectomy, with rates ranging from $20 \%$ to $73 \%$ (45-48), and include anastomotic leaks and strictures, and pulmonary complications. A study (47) examining limited esophageal resection for patients with HGD or intramucosal carcinoma demonstrated good clinical outcomes with less perioperative risk, including no deaths and a lower complication rate $(20.8 \%)$, when compared with the traditional radical esophagectomy. The reasoning behind undertaking such a major operation when only HGD has been found is largely based on data suggesting that when HGD is present there is already a 38\% to $50 \%$ rate of occult adenocarcinoma, although these numbers are based on a relatively small series of patients $(46,49)$.

\section{ENDOSCOPIC THERAPY FOR HGD AND INTRAMUCOSAL CARCINOMA IN BE}

Considering the fact that numerous patients are not good surgical candidates when diagnosed with dysplasia in BE, alternative therapies, mainly endoscopic, have been explored for several years now. More and more patients who may be surgical candidates are also becoming interested in these alternative therapies as they evolve. Numerous techniques have been tried, all with a view of ablating the dysplastic area, and some with the additional goal of ablating the BE completely. The principle of many of these techniques is to use thermal energy to necrose the columnar BE. In an anacid environment, one then hopes that the esophageal lining is replaced with normal squamous epithelium. Argon plasma coagulation (50), potassium-titanyl-phosphate lasers (51), multipolar electrocoagulation $(52,53)$ and liquid nitrogen cryoablation $(54)$ have all been reported in this context. Results are mixed, but a resounding theme tends to be promising preliminary results followed by less impressive results when applied to a larger group of patients. Of additional concern is the risk of development of 'buried glands', or columnar epithelium underneath the new squamous epithelium. Surveillance of these changes is difficult, and there has been one report of adenocarcinoma arising from this tissue (55). Photodynamic therapy (PDT) has been studied in various forms in the treatment of BE. It consists of the administration of a photosensitizer, followed by laser light application to the target tissue, in this case, the esophagus. The light releases intracellular free radicals, resulting in a type of burn that heals, in the absence of acid, with squamous epithelium. There are currently two types of photosensitizers - porfimer sodium (Photofrin, Axcan Pharma Inc, Canada) and 5-aminolevulinic acid. While the latter has a much better side effect profile due to its rapid clearance from the body, it does not appear to give a deep enough injury, thereby resulting in lower rates of ablation of $\mathrm{BE}(56-59)$ when compared with porfimer sodium cases (39). However, the deeper burn of porfimer sodium is not without a price, because rates of stricture formation are higher and the drug lasts in the system for weeks, thereby placing the patient at risk of serious skin injury from sun exposure.

Endoscopic mucosal resection was initially described as a technique for removing nodules or suspect lesions in $\mathrm{BE}$, and has been shown to be efficacious (60-65). However, it has further evolved, and now seems most promising when it is used in an attempt to remove all of the $\mathrm{BE}$, and the patient then undergoes PDT for ablation of any remaining BE. Results from a small series of patients are promising (66-68), and the logic behind such combination therapy seems compelling. However, as with all of these techniques, we await larger multicentre trials with appropriate follow-up to detect potential complications and recurrences.

\section{ROLE OF ENDOSCOPIC ULTRASOUND IN BE}

Endoscopic ultrasound has the potential to enhance the care of patients with BE, albeit after the diagnosis of dysplasia has been made. Although it has not been shown to be overly efficacious at discerning the level of invasion of a suspect lesion itself, it can assess for lymph node involvement and/or distant metastasis.

\section{SUMMARY}

When I see a patient with chronic reflux symptoms, I do discuss the possibility of screening for BE, and outline what would happen if we did find the condition, or if we found dysplasia or adenocarcinoma. In patients with known BE, I screen them every two years with endoscopy and four-quadrant biopsies every $2 \mathrm{~cm}$, plus biopsies of any suspect lesions. I also 
ensure they are on long-term proton pump inhibitor therapy. After a number of negative endoscopies, I may increase the interval of screening to every three to four years. If I find lowgrade dysplasia, I arrange for a repeat endoscopy in six months. If HGD is seen in a nodule, after an endoscopic ultrasound has ruled out metastatic disease, I will then discuss treatment options, including surgery and endoscopy, making sure they are aware that endoscopic therapies are still relatively new and long-term data are not yet available. If HGD is found in random biopsies, I will again discuss options, but often repeat the endoscopy in three months with repeat biopsies. If the dysplasia is still present, I will outline options such as endoscopic mucosal resection of the entire BE, and/or PDT, versus surgical esophagectomy.

\section{REFERENCES}

1. Ofman JJ, Lewin K, Ramers C, Ippoliti A, Lieberman D, Weinstein W. The economic impact of the diagnosis of dysplasia in Barrett's esophagus. Am J Gastroenterol 2000;95:2946-52.

2. Shaheen NJ, Green B, Medapalli RK, et al. The perception of cancer risk in patients with prevalent Barrett's esophagus enrolled in an endoscopic surveillance program. Gastroenterology 2005;129:429-36.

3. Conio M, Blanchi S, Lapertosa G, et al. Long-term endoscopic surveillance of patients with Barrett's esophagus. Incidence of dysplasia and adenocarcinoma: A prospective study. Am J Gastroenterol 2003;98:1931-9.

4. Drewitz DJ, Sampliner RE, Garewal HS. The incidence of adenocarcinoma in Barrett's esophagus: A prospective study of 170 patients followed 4.8 years. Am J Gastroenterol 1997;92:212-5.

5. Cameron AJ, Ott BJ, Payne WS. The incidence of adenocarcinoma in columnar-lined (Barrett's) esophagus. N Engl J Med 1985;313:857-9.

6. Eckardt VF, Kanzler G, Bernhard G. Life expectancy and cancer risk in patients with Barrett's esophagus: A prospective controlled investigation. Am J Med 2001;111:33-7.

7. Katz D, Rothstein R, Schned A, Dunn J, Seaver K, Antonioli D. The development of dysplasia and adenocarcinoma during endoscopic surveillance of Barrett's esophagus. Am J Gastroenterol 1998;93:536-41.

8. Williamson WA, Ellis FH Jr, Gibb SP, et al. Barrett's esophagus. Prevalence and incidence of adenocarcinoma. Arch Intern Med 1991;151:2212-6

9. Blot WJ, Devesa SS, Kneller RW, Fraumeni JF Jr. Rising incidence of adenocarcinoma of the esophagus and gastric cardia. JAMA 1991;265:1287-9.

10. Bytzer P, Christensen PB, Damkier P, Vinding K, Seersholm N. Adenocarcinoma of the esophagus and Barrett's esophagus: A population-based study. Am J Gastroenterol 1999;94:86-91.

11. Cameron AJ, Zinsmeister AR, Ballard DJ, Carney JA. Prevalence of columnar-lined (Barrett's) esophagus. Comparison of populationbased clinical and autopsy findings. Gastroenterology 1990;99:918-22.

12. Gerson LB, Shetler K, Triadafilopoulos G. Prevalence of Barrett's esophagus in asymptomatic individuals. Gastroenterology 2002;123:461-7.

13. Hirota WK, Loughney TM, Lazas DJ, Maydonovitch CL, Rholl V, Wong RK. Specialized intestinal metaplasia, dysplasia, and cancer of the esophagus and esophagogastric junction: Prevalence and clinical data. Gastroenterology 1999;116:277-85.

14. Mann NS, Tsai MF, Nair PK. Barrett's esophagus in patients with symptomatic reflux esophagitis. Am J Gastroenterol 1989;84:1494-6

15. Rex DK, Cummings OW, Shaw M, et al. Screening for Barrett's esophagus in colonoscopy patients with and without heartburn. Gastroenterology 2003;125:1670-7.

16. Voutilainen M, Sipponen P, Mecklin JP, Juhola M, Farkkila M. Gastroesophageal reflux disease: Prevalence, clinical, endoscopic and histopathological findings in 1,128 consecutive patients referred for endoscopy due to dyspeptic and reflux symptoms. Digestion 2000; 61:6-13

17. Winters C Jr, Spurling TJ, Chobanian SJ, et al. Barrett's esophagus. A prevalent, occult complication of gastroesophageal reflux disease. Gastroenterology 1987; 92:118-24

18. Ronkainen J, Aro P, Storskrubb T, et al. Prevalence of Barrett's esophagus in the general population: An endoscopic study. Gastroenterology 2005;129:1825-31.
19. Fass R, Hell RW, Garewal HS, et al. Correlation of oesophageal acid exposure with Barrett's oesophagus length. Gut 2001;48:310-3.

20. Levine DS, Blount PL, Rudolph RE, Reid BJ. Safety of a systematic endoscopic biopsy protocol in patients with Barrett's esophagus. Am J Gastroenterol 2000;95:1152-7.

21. Hillman LC, Chiragakis L, Clarke AC, Kaushik SP, Kaye GL. Barrett's esophagus: Macroscopic markers and the prediction of dysplasia and adenocarcinoma. J Gastroenterol Hepatol 2003;18:526-33.

22. Canto MI, Setrakian S, Petras RE, Blades E, Chak A, Sivak MV Jr. Methylene blue selectively stains intestinal metaplasia in Barrett's esophagus. Gastrointest Endosc 1996;44:1-7.

23. Canto MI, Setrakian S, Willis J, et al. Methylene blue-directed biopsies improve detection of intestinal metaplasia and dysplasia in Barrett's esophagus. Gastrointest Endosc 2000;51:560-8.

24. Dave U, Shousha S, Westaby D. Methylene blue staining: Is it really useful in Barrett's esophagus? Gastrointest Endosc 2001;53:333-5.

25. Ragunath K, Krasner N, Raman VS, Haqqani MT, Cheung WY. A randomized, prospective cross-over trial comparing methylene blue-directed biopsy and conventional random biopsy for detecting intestinal metaplasia and dysplasia in Barrett's esophagus. Endoscopy 2003;35:998-1003

26. Wo JM, Ray MB, Mayfield-Stokes S, et al. Comparison of methylene blue-directed biopsies and conventional biopsies in the detection of intestinal metaplasia and dysplasia in Barrett's esophagus: A preliminary study. Gastrointest Endosc 2001;54:294-301.

27. Kara MA, Peters FP, Ten Kate FJ, Van Deventer SJ, Fockens P, Bergman JJ. Endoscopic video autofluorescence imaging may improve the detection of early neoplasia in patients with Barrett's esophagus. Gastrointest Endosc 2005;61:679-85.

28. Kara MA, Smits ME, Rosmolen WD, et al. A randomized crossover study comparing light-induced fluorescence endoscopy with standard videoendoscopy for the detection of early neoplasia in Barrett's esophagus. Gastrointest Endosc 2005;61:671-8.

29. Messmann H, Knuchel R, Baumler W, Holstege A, Scholmerich J. Endoscopic fluorescence detection of dysplasia in patients with Barrett's esophagus, ulcerative colitis, or adenomatous polyps after 5-aminolevulinic acid-induced protoporphyrin IX sensitization. Gastrointest Endosc 1999;49:97-101.

30. Niepsuj K, Niepsuj G, Cebula W, et al. Autofluorescence endoscopy for detection of high-grade dysplasia in short-segment Barrett's esophagus. Gastrointest Endosc 2003;58:715-9.

31. Panjehpour M, Overholt BF, Vo-Dinh T, Haggitt RC, Edwards DH, Buckley FP III. Endoscopic fluorescence detection of high-grade dysplasia in Barrett's esophagus. Gastroenterology 1996;111:93-101.

32. Guelrud M, Herrera I, Essenfeld H, Castro J. Enhanced magnification endoscopy: A new technique to identify specialized intestinal metaplasia in Barrett's esophagus. Gastrointest Endosc 2001;53:559-65.

33. Evans JA, Nishioka NS. The use of optical coherence tomography in screening and surveillance of Barrett's esophagus. Clin Gastroenterol Hepatol 2005;3(Suppl 1):S8-11

34. Evans JA, Poneros JM, Bouma BE, et al. Optical coherence tomography to identify intramucosal carcinoma and high-grade dysplasia in Barrett's esophagus. Clin Gastroenterol Hepatol 2006;4:38-43.

35. Isenberg G, Sivak MV Jr, Chak A, et al. Accuracy of endoscopic optical coherence tomography in the detection of dysplasia in Barrett's esophagus: A prospective, double-blinded study. Gastrointest Endosc 2005;62:825-31.

36. Brand S, Wang TD, Schomacker KT, et al. Detection of high-grade dysplasia in Barrett's esophagus by spectroscopy measurement of 5-aminolevulinic acid-induced protoporphyrin IX fluorescence. Gastrointest Endosc 2002;56:479-87.

37. Pfefer TJ, Paithankar DY, Poneros JM, Schomacker KT, Nishioka NS Temporally and spectrally resolved fluorescence spectroscopy for the detection of high grade dysplasia in Barrett's esophagus. Lasers Surg Med 2003;32:10-6.

38. Kara MA, Peters FP, Rosmolen WD, et al. High-resolution endoscopy plus chromoendoscopy or narrow-band imaging in Barrett's esophagus: A prospective randomized crossover study. Endoscopy 2005;37:929-36.

39. Overholt BF, Lightdale CJ, Wang KK, et al; International Photodynamic Group for High-Grade Dysplasia in Barrett's Esophagus. Photodynamic therapy with porfimer sodium for ablation of high-grade dysplasia in Barrett's esophagus: International, partially blinded, randomized phase III trial. Gastrointest Endosc 2005;62:488-98. 
40. Oelschlager BK, Barreca M, Chang L, Oleynikov D, Pellegrini CA. Clinical and pathologic response of Barrett's esophagus to laparoscopic antireflux surgery. Ann Surg 2003;238:458-64; discussion 464-6.

41. Csendes A, Braghetto I, Burdiles P, et al. Long-term results of classic antireflux surgery in 152 patients with Barrett's esophagus: Clinical, radiologic, endoscopic, manometric, and acid reflux test analysis before and late after operation. Surgery 1998;123:645-57.

42. Desai KM, Soper NJ, Frisella MM, Quasebarth MA, Dunnegan DL, Brunt LM. Efficacy of laparoscopic antireflux surgery in patients with Barrett's esophagus. Am J Surg 2003;186:652-9.

43. O'Riordan JM, Byrne PJ, Ravi N, Keeling PW, Reynolds JV. Long-term clinical and pathologic response of Barrett's esophagus after antireflux surgery. Am J Surg 2004;188:27-33.

44. Tigges H, Fuchs KH, Maroske J, et al. Combination of endoscopic argon plasma coagulation and antireflux surgery for treatment of Barrett's esophagus. J Gastrointest Surg 2001;5:251-9.

45. Heitmiller RF, Redmond M, Hamilton SR. Barrett's esophagus with high-grade dysplasia. An indication for prophylactic esophagectomy. Ann Surg 1996;224:66-71.

46. Rice TW, Falk GW, Achkar E, Petras RE. Surgical management of high-grade dysplasia in Barrett's esophagus. Am J Gastroenterol 1993;88:1832-6.

47. Stein HJ, Feith M, Mueller J, Werner M, Siewert JR. Limited resection for early adenocarcinoma in Barrett's esophagus. Ann Surg 2000;232:733-42.

48. Thomas P, Doddoli C, Neville P, et al. Esophageal cancer resection in the elderly. Eur J Cardiothorac Surg 1996;10:941-6.

49. Pera M, Trastek VF, Carpenter HA, Allen MS, Deschamps C, Pairolero PC. Barrett's esophagus with high-grade dysplasia: An indication for esophagectomy? Ann Thorac Surg 1992;54:199-204.

50. Attwood SE, Lewis CJ, Caplin S, Hemming K, Armstrong G. Argon beam plasma coagulation as therapy for high-grade dysplasia in Barrett's esophagus. Clin Gastroenterol Hepatol 2003;1:258-63.

51. Bowers SP, Mattar SG, Waring PJ, et al. KTP laser ablation of Barrett's esophagus after anti-reflux surgery results in long-term loss of intestinal metaplasia. Potassium-titanyl-phosphate. Surg Endosc 2003;17:49-54.

52. Kovacs BJ, Chen YK, Lewis TD, DeGuzman LJ, Thompson KS. Successful reversal of Barrett's esophagus with multipolar electrocoagulation despite inadequate acid suppression. Gastrointest Endosc 1999;49:547-53.

53. Sampliner RE, Faigel D, Fennerty MB, et al. Effective and safe endoscopic reversal of nondysplastic Barrett's esophagus with thermal electrocoagulation combined with high-dose acid inhibition: A multicenter study. Gastrointest Endosc 2001;53:554-8.

54. Johnston MH, Eastone JA, Horwhat JD, Cartledge J, Mathews JS, Foggy JR. Cryoablation of Barrett's esophagus: A pilot study. Gastrointest Endosc 2005;62:842-8.

55. Van Laethem JL, Peny MO, Salmon I, Cremer M, Deviere J. Intramucosal adenocarcinoma arising under squamous re-epithelialisation of Barrett's oesophagus. Gut 2000;46:574-7.
56. Ackroyd R, Brown NJ, Davis MF, Stephenson TJ, Stoddard CJ, Reed MW. Aminolevulinic acid-induced photodynamic therapy: Safe and effective ablation of dysplasia in Barrett's esophagus. Dis Esophagus 2000;13:18-22.

57. Ackroyd R, Tam W, Schoeman M, Devitt PG, Watson DI. Prospective randomized controlled trial of argon plasma coagulation ablation vs endoscopic surveillance of patients with Barrett's esophagus after antireflux surgery. Gastrointest Endosc 2004:59:1-7.

58. Barr H, Shepherd NA, Dix A, Roberts DJ, Tan WC, Krasner N. Eradication of high-grade dysplasia in columnar-lined (Barrett's) oesophagus by photodynamic therapy with endogenously generated protoporphyrin IX. Lancet 1996;348:584-5.

59. Gossner L, Stolte M, Sroka R, et al. Photodynamic ablation of high-grade dysplasia and early cancer in Barrett's esophagus by means of 5-aminolevulinic acid. Gastroenterology 1998;114:448-55.

60. Ell C, May A, Gossner L, et al. Endoscopic mucosal resection of early cancer and high-grade dysplasia in Barrett's esophagus. Gastroenterology 2000;118:670-7.

61. Giovannini M, Bories E, Pesenti C, et al. Circumferential endoscopic mucosal resection in Barrett's esophagus with high-grade intraepithelial neoplasia or mucosal cancer. Preliminary results in 21 patients. Endoscopy 2004;36:782-7.

62. Larghi A, Lightdale CJ, Memeo L, Bhagat G, Okpara N, Rotterdam H. EUS followed by EMR for staging of high-grade dysplasia and early cancer in Barrett's esophagus. Gastrointest Endosc 2005;62:16-23.

63. May A, Gossner L, Pech O, et al. Intraepithelial high-grade neoplasia and early adenocarcinoma in short-segment Barrett's esophagus (SSBE): Curative treatment using local endoscopic treatment techniques. Endoscopy 2002;34:604-10.

64. Mino-Kenudson M, Brugge WR, Puricelli WP, et al. Management of superficial Barrett's epithelium-related neoplasms by endoscopic mucosal resection: Clinicopathologic analysis of 27 cases. Am J Surg Pathol 2005;29:680-6.

65. Seewald S, Akaraviputh T, Seitz U, et al. Circumferential EMR and complete removal of Barrett's epithelium: A new approach to management of Barrett's esophagus containing high-grade intraepithelial neoplasia and intramucosal carcinoma. Gastrointest Endosc 2003;57:854-9.

66. Buttar NS, Wang KK, Lutzke LS, Krishnadath KK, Anderson MA Combined endoscopic mucosal resection and photodynamic therapy for esophageal neoplasia within Barrett's esophagus. Gastrointest Endosc 2001;54:682-8

67. Pacifico RJ, Wang KK, Wongkeesong LM, Buttar NS, Lutzke LS. Combined endoscopic mucosal resection and photodynamic therapy versus esophagectomy for management of early adenocarcinoma in Barrett's esophagus. Clin Gastroenterol Hepatol 2003;1:252-7.

68. Wolfsen HC, Hemminger LL, Raimondo M, Woodward TA. Photodynamic therapy and endoscopic mucosal resection for Barrett's dysplasia and early esophageal adenocarcinoma. South Med J 2004;97:827-30. 


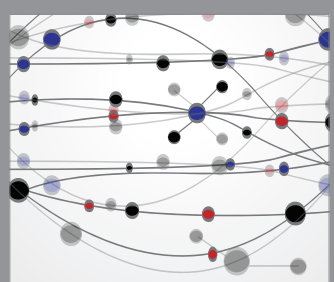

The Scientific World Journal
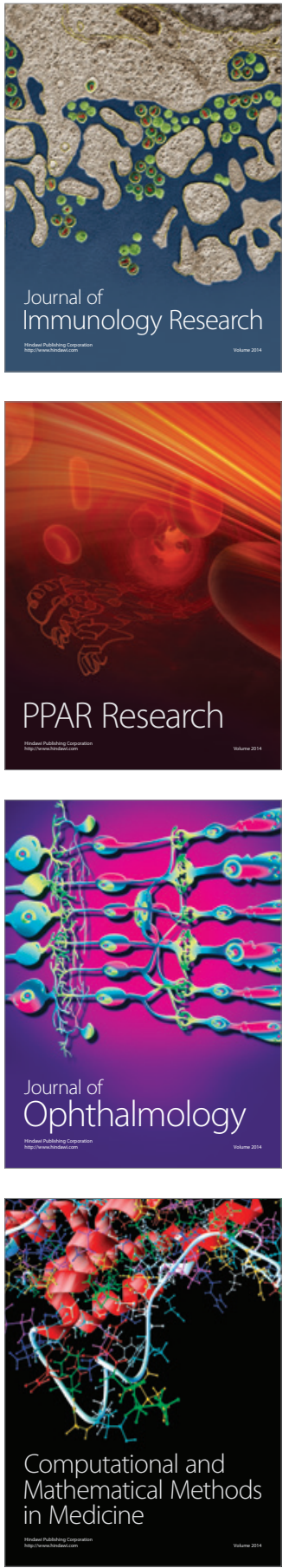

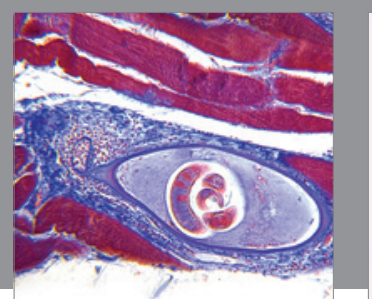

Gastroenterology Research and Practice

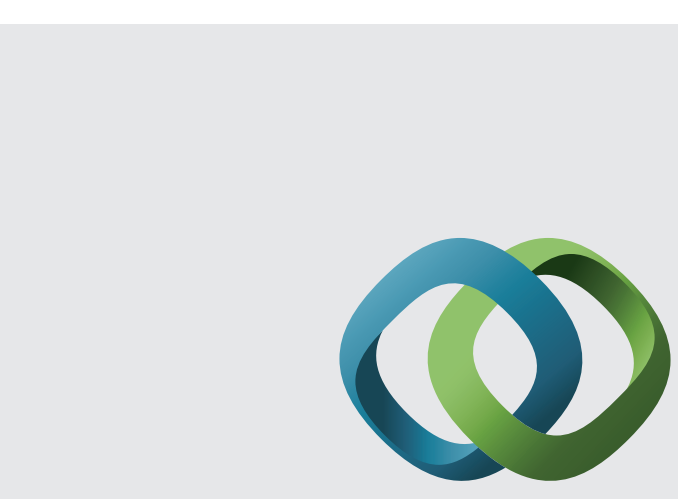

\section{Hindawi}

Submit your manuscripts at

http://www.hindawi.com
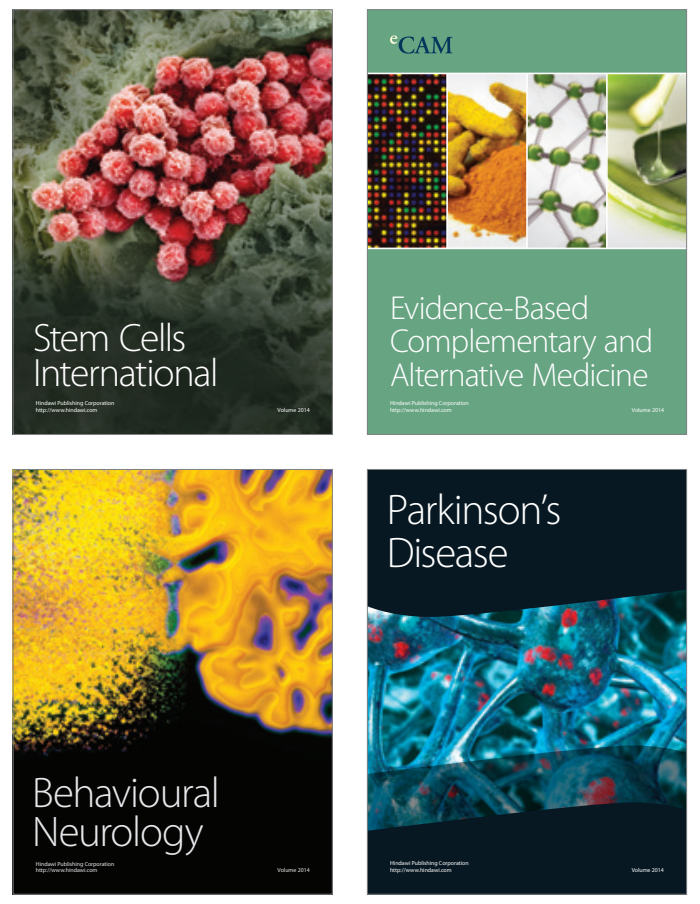
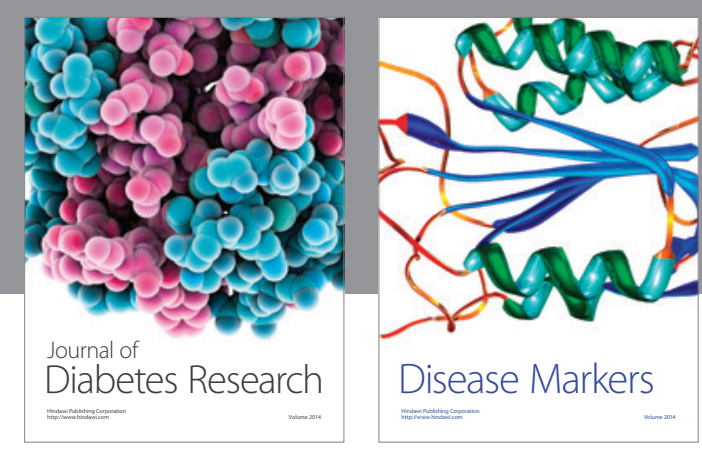

Disease Markers
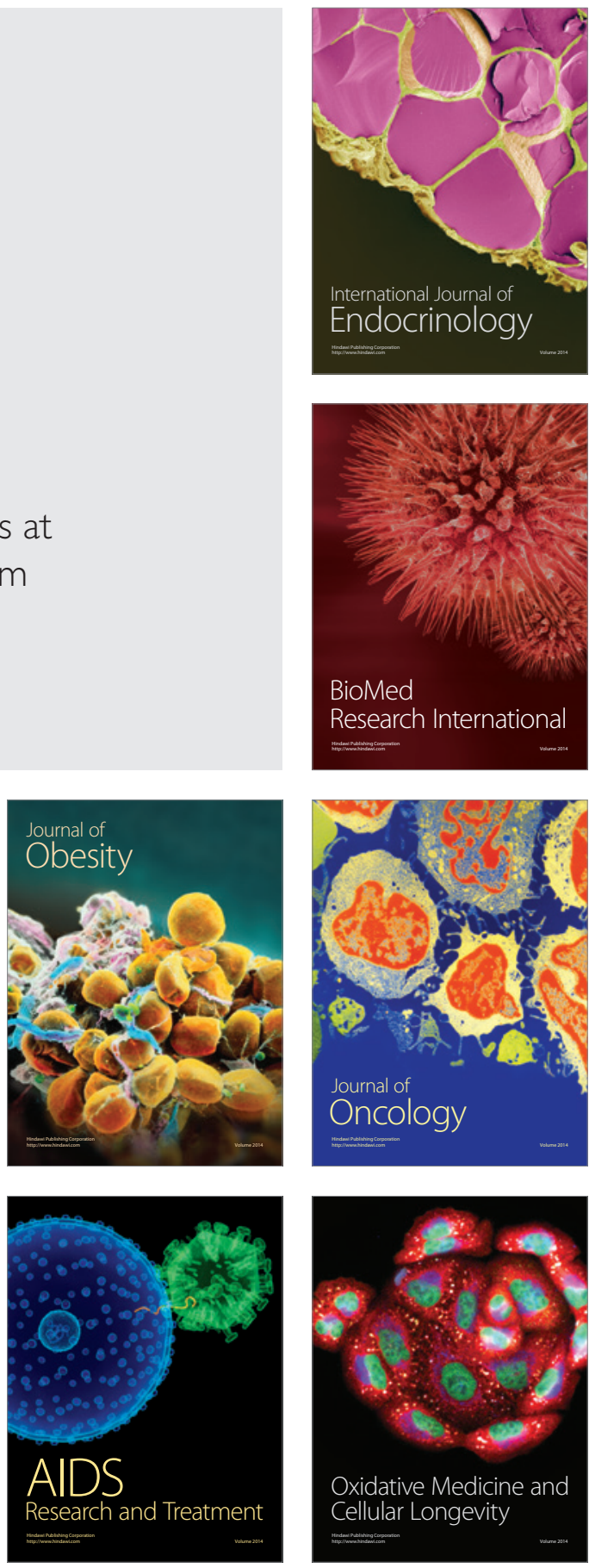